\title{
Prerequisites for the Industrial Policy Formation of the Country in Conditions of Transition to the Sixth Technology Revolution
}

\author{
Oleksandra I. KarintseVai, AnNa V. Dyachenkoii, \\ S VItLANa V. TarasenKoiii, Mrkola O. KHARchenKo ${ }^{\text {iv }}$
}

\begin{abstract}
In the conditions of transition to the sixth technology revolution, it is important to determine the vector of the formation of industrial policy and the points of growth of the country, considering the specifics of its development and potential resources. For Ukraine, the choice of a niche, industry, directions that would become the mainstream of sustainable development of the country continues to be relevant. Main purpose of the article is to justify the hypothesis of the need to form a niche orientation of the industrial policy of the country in the conditions of transition to the sixth technology revolution. A classic model of industrial policy is characteristic for Ukraine. In conditions of decentralization and the need for uniform development of regions for the country, it is optimal to use a system model that initiates the diversification of production of goods and services and cost optimization. An important element in the cluster model is the definition of the main niche that unites innovative clusters of territories. In Ukraine, there is some positive dynamics of growth in value added created in the country, up to 2010. At the same time, the absolute values of the gross value-added index created in Ukraine in general are several times smaller (or even 10 times) than the created gross value added in manufacturing industry of leading countries. The country enters a new technological cycle without having a strong industrial base. This defines its low launch opportunities for introducing design innovations and further sustainable development. It is proposed to form industrial robotics as a leading niche in the country's industry, which would become a point of growth for the export of products with high added value. This choice is due to the socio-economic progress of mankind in the 21 st century and the indices of the development of industrial robotics in recent years.
\end{abstract}

Keywords: industrial policy, technological structure, niche, robotics, industrial multiplier, Kondratieff wave, manufacturing industry, gross value added, model, Ukraine.

УДК 338.2

JEL Codes: E60, L52

Introduction. Vectors of the economic systems development are determined by socially and economically acceptable practices in society, both in terms of saving, consumption, and in the capacities of society to produce educational, technological, and cultural innovations. In addition, the growing dematerialization of production of economic entities is caused by the formation and further spread of business processes in the Internet environment. Industry creates the basis for an intensive model of the country's development. In turn, the development of the industrial complex is ensured by the industrial policy of the country.

${ }^{i}$ Oleksandra I. Karintseva, C.Sc. (Economics), Associate Professor, Department of Economics, Entrepreneurship and Business Administration, Sumy State University;

${ }^{i i}$ Anna V. Dyachenko, Postgraduate Student, Department of Economics, Entrepreneurship and Business Administration, Sumy State University;

${ }^{i i i}$ Svitlana V. Tarasenko, C.Sc. (Economics), Senior Lecturer, Department of International Economic Relations, Education and Research Institute for Business Technologies "UAB", Sumy State University;

${ }^{i v}$ Mykola O. Kharchenko, C.Sc. (Economics), Associate Professor, Department of Economics, Entrepreneurship and Business Administration, Sumy State University.

(C) O. I. Karintseva, A. V. Dyachenko, S. V. Tarasenko, M. O. Kharchenko, 2018.

https://doi.org/10.21272/mer.2018.82.04

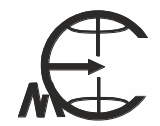


Problem statement. The work of Rifkin J. [7] is devoted to the questions of the formation of industrial policy in the countries. The influence of long waves on the processes of industrial development is considered in the work of Grinin L. E. [3] et al.

Kindzersky $\mathrm{Yu}$. V. substantiates the possible specialization of Ukraine in the world division of labor [4]. Khaustova V. E. considers the specifics of the implementation of industrial policy in the developed and developing countries of the world in 2014 [5]. The nonindustrial transformation of the industrial potential of Ukraine is considered in the collective monograph of the researchers of the Institute of Economics and Forecasting of the National Academy of Sciences of Ukraine [2].

The UNIDO report "Industrial Development Report 2018. Demand for Manufacturing Products: A Factor of Comprehensive and Sustainable Industrial Development" analyzes trends in the development of the world's industry [6]. World Investment Report 2017 UNCTAD identifies the links between the level of development of countries, investments and the digitization of the economy [10].

In the conditions of transition to the sixth technology revolution, it is important to determine the vector of the formation of industrial policy and the points of growth of the country, considering the specifics of its development and potential resources. For Ukraine, the choice of a niche, industry, directions that would become the mainstream of sustainable development of the country continues to be relevant.

Main purpose of the article is to justify the hypothesis of the need to form a niche orientation of the industrial policy of the country in the conditions of transition to the sixth technology revolution.

Results of the research. At present, the world is in a phase of decline of the fifth long wave, the upper turning point of which is defined as the financial crisis of 2008 [3]. In connection with the strengthening of the state role in the economy, some cyclic-forming tendencies of world economic development were seriously violated [3], and in fact, since 1994, there has been no significant transformation of technical and economic paradigm: the industry semiconductor manufacturing remained the main industry based on which the industry developed, both in the fourth long wave and in the phase of the fifth long wave.

In fact, the development of the Internet, the development of mobile communications and the full penetration of digital technologies into all spheres of society were the basic innovations of the fifth long wave. Cloud data centers, graphics processors, search engines, voice assistants, drones lead to a radical change in both production and consumption, increasing the worker productivity.

Large-scale application of ICT in the XXI century contributed not only to increasing employment in new industries, but also to reducing it through the modernization of manufacturing industries that have entered the maturity phase of their life cycle.

An increase in the unemployment rate in developed countries, as well as a decrease in the degree of population participation in the labor force at the beginning of the 21 st century were the signs of modification of the long wave (a large cycle). The involvement of the huge resources of cheap labor into the world economy from China and India was another reason for this type of modification.

In the current technological trends, the technological, rather than the design branch of scientific and technological revolution predominates. Computing technologies, communication media (first, the Internet and mobile applications) are developed at a very high speed, determining the changes in economic reality. But they do not belong to the design branch of scientific and technological revolution. 
Oleksandra I. Karintseva, Anna V. Dyachenko, Svitlana V. Tarasenko, Mykola O. Kharchenko. Prerequisites for the Industrial Policy Formation of the Country in Conditions of Transition to the Sixth Technology Revolution

Design innovations define the beginning of the ascending wave of the long cycle, the transition to a new technological order, within which the formation of the country's industrial policy in the areas of innovation takes place [6].

Today, three basic models of industrial policy have emerged:

1) classical, or vertical model (it was used in Japan in 1950-1960 of the XX century);

2) neoclassical or horizontal model - soft forms of state intervention - creating framework conditions for efficient allocation of resources;

3) a system model (Scandinavian policy based on a cluster approach), based on the interaction of the institutional and evolutionary theory with the implementation of the neoSchumpeter approach to the process of creating innovations [8].

The use of a horizontal model of industrial policy is argued by the need to prevent system failures in the economy through the methods of soft horizontal intervention in the economy, covering all sectors. The purpose of such interventions is to improve the environment of partnership interactions between economic agents and the formation of triple spirals.

Classical industrial policy appeals to the creation of a critical set of industries, and neoclassical policy refers to the introduction of a critical mass of effective market institutions. In turn, the system model appeals to the formation of a critical mass of innovative clusters. The development of cluster organization of the economy (network structure) provides for activation of registration and diversification of industries (the opening of new sectors) and the formation of a new cost structure.

In his work Behrens argues that clusters can change significantly in a relatively short time (just over 10 years). On the one hand, such a rapid change can be associated with the processes of development and changes in the industrial environment, on the other hand they are associated with the effects of production concentration in one place [1]

A classic model of industrial policy is characteristic for Ukraine. In conditions of decentralization and the need for uniform development of regions for the country, it is optimal to use a system model that initiates the diversification of production of goods and services and cost optimization. An important element in the cluster model is the definition of the main niche that unites innovative clusters of territories.

The report of the MAPI Foundation presented an assessment of the contribution of industry to the US economy in 2016. The traditional statistical assessment does not include complex integrated value chain generated by production activity: the cost of initial resources, raw materials, materials and services that are needed in production activities (raw materials extraction, production and delivery of components, consumables and services, R\&D, investment activity, design centers, transport, energy, engineering and service companies, etc.); as well as the cost of services for the delivery, distribution and sale of the final products (warehousing and transport logistics, wholesalers, service providers, distributors and retailers, advertising and marketing).

MAPI Foundation calculated the industrial multiplier in the economy, which was 3.6 in 2016. This means that every $\$ 1$ of added value in the industrial sector generates $\$ 3.6$ of added value in the economy along the entire value chain. Estimates generally showed that the entire value chain in industry accounts for more than one-third of US GDP [13].

The MAPI Foundation estimates of the multiplier effect of domestic industrial production in 2016 are more than twice as high as earlier estimates. So, in 2014, the MAPI Foundation gave the multiplier for the industry "only" in 1.33 [14].

An important indicator of developed industry of the country is the volume of gross value added of the manufacturing industry (that is, the volume of the value that was created inside 
О. І. Карінцева, А. В. Дяченко, С. В. Тарасенко, М. О. Харченко. Передумови формування промислової політики країни в умовах переходу до шостого технологічного укладу

the country). Let's compare the gross value added created by the manufacturing industry of the leading countries of the world (Table 1). For Ukraine, the data on the created added value in the country are available (Table 2 ).

Table 1

Gross value added created by manufacturing industry of leading countries of the world in 2000-2015, billions of dollars (calculated from OECD data) [11]

\begin{tabular}{|c|c|c|c|c|c|}
\hline Country & 2000 & 2005 & 2010 & 2015 & $\begin{array}{c}\text { Rate of increase } \\
2015 / 2000, \%\end{array}$ \\
\hline China & 252 & 509 & 1400 & 2973 & 1079,8 \\
\hline USA & 1015 & 1163 & 1208 & 2170 & 113,8 \\
\hline India & 47 & 90 & 178 & 311 & 561,7 \\
\hline Japan & 770 & 712 & 842 & 810 & 5,2 \\
\hline Germany & 308 & 461 & 556 & 690 & 124,0 \\
\hline
\end{tabular}

The data of Table 1 indicate the highest growth rate of gross value added in China in 2015 compared to 2000 (at $1079.8 \%$ ). High rates of growth were in India (561.7 \%) and Germany $(124.0 \%)$. But the absolute value of gross value added in India, Japan, Germany is several times less than the values of China and the United States.

Gross value added, created in Ukraine in 2000-2015, billion dollars

Table 2

(calculated according to ukrstat, data of the NBU at the rate of hryvnia for 2000-2015)

\begin{tabular}{|c|c|c|c|c|c|}
\hline Country & 2000 & 2005 & 2010 & 2015 & $\begin{array}{c}\text { Rate of increase } \\
2015 / 2000, \%\end{array}$ \\
\hline Ukraine & 28 & 79 & 119 & 77 & 175,0 \\
\hline
\end{tabular}

In Ukraine, there is some positive dynamics of growth in value added created in the country, up to 2010. At the same time, the absolute values of the gross value-added index created in Ukraine in general are several times smaller (or even 10 times) than the created gross value added in manufacturing industry of leading countries.

Table 3 shows the dynamics of indices of industrial production in Ukraine from 2010 to 2018 .

The data of Table 3 show a decline in industrial production in Ukraine during 2010-2018. In other words, the country enters a new technological cycle without having a strong industrial base. This defines its low launch opportunities for introducing design innovations and further sustainable development.

Table 3

Dynamics of indices of industrial production in Ukraine, 2010-2018, \% [15]

\begin{tabular}{|c|c|c|c|c|c|c|c|c|}
\hline Year & 2010 & 2011 & 2012 & 2013 & 2014 & 2015 & 2016 & 2017 \\
\hline Index & 112,2 & 103,4 & 94,4 & 99,0 & 82,8 & 98,4 & 103,1 & 97,1 \\
\hline
\end{tabular}


Oleksandra I. Karintseva, Anna V. Dyachenko, Svitlana V. Tarasenko, Mykola O. Kharchenko. Prerequisites for the Industrial Policy Formation of the Country in Conditions of Transition to the Sixth Technology Revolution

In our opinion, Ukraine needs to define a niche in the industrial sector that would become a point of growth for the export of products with high added value. This niche can become industrial robotics.

According to the survey of the world market of robotics, the growth rate of the industrial robotics market outruns the growth rates of world GDP: the average annual growth in sales of industrial robots was $12 \%$ between 2011 and 2016. In 2016, 294,000 industrial robots were sold, and the total market volume reached $\$ 13.1$ billion (considering software and integration services, the market exceeds $\$ 40$ billion).

The main characteristics of the service robotics market:

- the sales volume in 2015 was 48 thousand of professional service robots, in 2016 59 thousand, the growth rate was $23 \%$;

- the market volume of professional service robots composed \$ 4.7 billion;

- according to IFR estimates, the average annual growth rate of the world's industrial fleet will be $14 \%$ in the industrial years 2018-2020;

- $91 \%$ of all industrial robots was established in the manufacturing sector in 2016.

- In 2011-2016 the average annual growth rate of sales in all branches of manufacturing was $13 \% ; 12 \%$ in automotive industry and $19 \%$ in electronic industry. The average annual growth rate of sales in all branches of manufacturing in 2011-2016 was $13 \%$; in automotive industry $-12 \%$, and in electronic industry $-19 \%$;

- $74 \%$ of world sales of industrial robots are accounted for five countries: China (30\%), the Republic of Korea (14\%), Japan (13\%), the United States (11\%) and Germany (7\%);

- the main manufacturers of industrial robots are Japanese enterprises: FANUC, Yaskawa, Kawasaki, Nachi, Denso, Mitsubishi, Epson и Omron and enterprises from the EU zone: ABB, Stäubli, Kuka, Comau, Universal Robots. The United States leads (49\%) in the service robotics industry;

- in absolute terms the most robots are sold to logistics ( 25 thousand units), military use $(\sim 11,000)$, to commercial spaces $(\sim 7,000)$, field works and exoskeletons $(\sim 6,000) .69 \%$ of robots purchased for home use in 2016 were mostly vacuum cleaners or machines for household tasks, $31 \%$ belonged to toys.

The directions, which will form the basis of the service robotics market by 2020, are:

- logistic systems (include logistics inside the premises, unmanned and air delivery vehicles outside the premises);

- robots for customer service;

- industrial exoskeletons;

- robots for household tasks (personal assistants) [9].

Conclusions and prospects of further research. Thus, there is an industrial multiplier in the economy of each country, which means that each unit of added value in the industrial sector generates a certain added value in the economy along the entire value chain.

Ukraine enters the new sixth technology revolution without having a powerful industrial base. Industrial Production Indices of the country tend to decrease. This determines its low launch opportunities for introducing design innovations and further sustainable development.

It is proposed to form industrial robotics as a leading niche in the country's industry, which would become a point of growth for the export of products with high added value. This choice is due to the socio-economic progress of mankind in the 21 st century and the indices of the development of industrial robotics in recent years. 


\section{References}

1. Behrens, K. (2016). Agglomeration and clusters: Tools and insights from coagglomeration patterns. Canadian Journal of Economics, 4, 1293-1339.

2. Deineko, L. V. et al. (2016). Neoindustrialna transformatsiia promyslovoho potentsialu Ukrainy [Neoindustrial transformation of industrial potential of Ukraine]. K., 278.

3. Grinin, L. E. et al. (2017). Kondratyev:krizisy i prognozy $v$ svete teorii dlinnykh voln. Vzglyad iz sovremennosti [Kondratiev N. D.: crises and forecasts in the light of the theory of long waves. A glance from the present]. Moscow, 384.

4. Kindzersky, Yu. V. (2016). Antykryzova promyslova polityka: variant vitchyznianoho kontseptu [Anti-crisis industrial policy: variant of the domestic concept]. Bulletin of the National Academy of Sciences of Ukraine, 10, 27-42.

5. Haustova, V.E. (2015). Promyslova polityka v Ukraini $v$ umovakh intehratsii ta hlobalizatsii ekonomiky [Industrial policy in Ukraine in terms of integration and globalization of the economy]. K., 505.

6. Otchet o promyshlennom razvitii 2018. Spros na produktsiyu obrabatyvayushchey promyshlennosti: faktor vseokhvatyvayushchego $i$ ustoychivogo promyshlennogo razvitiya (2017). [Industrial Development Report 2018. Demand for Manufacturing Products: A Factor of Comprehensive and Sustainable Industrial Development]. UNIDO. Vienna.

7. Rifkin, J. (2014). Tretia promyshlennaya revolyutsiya. Kak gorizontalnyye vzaimodeystviya menyayut energetiku. ekonomiku $i$ mir $v$ tselom [Third Industrial Revolution. As horizontal interactions change the energy, the economy and the world as a whole]. Moscow, 410.

8. Smorodinskaya, N. V. (2015). Globalizirovannaya ekonomika: ot iyerarkhiy k setevomu ukladu [The globalized economy: from hierarchies to the network way of life]. M., 344.

9. Sberbank predstavil obzor mirovogo rynka robototekhniki [Sberbank presented an overview of the world market of robotics]. Retrieved from http://www.nanonewsnet.ru/news/2018/sberbankpredstavil-obzor-mirovogo-rynka-robototekhniki.

10. Doklad o mirovikh investitsiyakh 2017. Investitsii i tsifrovaya ekonomika. [World Investment Report (2017). Investment and the Digital Economy]. YuNKTAD.

11. Value added by activity. Retrieved from https://data.oecd.org/natincome/value-added-byactivity.htm.

12. Derzhavna sluzhba statystyky Ukrainy [State Statistics Service of Ukraine]. Retrieved from http://www.ukrstat.gov.ua.

13. Manufacturing-facts 2016. Retrieved from https://mapifoundation.org/manufacturingfacts/2016/9/13/how-important-is-us-manufacturing-today.

14. Manufacturing's Multiplier Effect is Stronger than Other Sectors'. Retrieved from http://www.themanufacturinginstitute.org/Research/Facts-About-Manufacturing/Economy-andJobs/Multiplier/Multiplier.aspx.

15. Indeks promyshlennogo proizvodstva [Industrial Production Index]. Retrieved from https://index.minfin.com.ua/economy/index/industrial/.

Manuscript received 10 October 2018

\section{Предпосылки формирования промышленной политики страны}

в условиях перехода к шестому технологическому укладу
АЛЕКСАНДРА ИВАНОВНА КАРИНЦЕВА*, АННА ВИКТОРОВНА ДЯЧЕНКО С ВетЛАНА ВИКТОРОВНА ТАРАСЕНКО***, НИКОЛАЙ АЛЕКСЕЕВИЧ ХАРЧЕНКО ${ }^{* * * *}$ 
Oleksandra I. Karintseva, Anna V. Dyachenko, Svitlana V. Tarasenko, Mykola O. Kharchenko. Prerequisites for the Industrial Policy Formation of the Country in Conditions of Transition to the Sixth Technology Revolution

* кандидат экономических наук, доцент, доцент кафедры экономики, предпринимательства и бизнес-администрирования Сумского государственного университета,

ул. Р.-Корсакова, 2, г. Сумы, 40007, Украина, тел.: 00-380-542-332223, e-mail: niko_kha@ukr.net

** аспирант кафедры экономики, предпринимательства и бизнес-администрирования Сумского государственного университета,

ул. Р.-Корсакова, 2, г. Сумы, 40007, Украина,

тел.: 00-380-542-332223, e-mail: a15dyachenko@ gmail.com

*** кандидат экономических наук, старший преподаватель кафедры международных экономических отномений Учебно-научного института бизнес-технологий «УАБД»

Сумского государственного университета,

ул. Р.-Корсакова, 2, г. Сумы, 40007, Украина,

тел.: 00-380-542-665042, e-mail: svitlana_tarasenko@ukr.net

***** кандидат экономических наук, доцент, доцент кафедры экономики, предпринимательства и бизнес-администрирования Сумского государственного университета,

ул. Р.-Корсакова, 2, г. Сумы, 40007, Украина,

тел.: 00-380-542-332223, e-mail: niko_kha@ukr.net

Актуальность исследования. В условиях перехода к шестому технологическому укладу актуальным является определение вектора формирования промышленной политики и точек роста страны с учетом особенностей ее развития и потенциальных ресурсов. Для Украины актуальным остается выбор ниши, области, направлений, которые сформировали бы основу устойчивого развития страны. Цель исследования. Обоснование гипотезы о необходимости формирования нишевой направленности промышленной политики страны в условиях перехода к шестому технологическому укладу. Результаты исследования. Для Украины характерна классическая модель промышленной политики. В условиях децентрализации и необходимости равномерного развития регионов для страны оптимальным является использование системной модели, инициирующей диверсификацию производства товаров, услуг и оптимизацию расходов отраслей. Важным элементом в рамках кластерной модели выступает определение основной ниши, объединяющей инновационные кластеры территорий. В Украине прослеживается положительная динамика роста добавленной стоимости, созданной в стране, до 2010 г. При этом абсолютные значения валовой добавленной стоимости, созданной в целом в Украине, в несколько раз меньше (а то и в 10 раз), чем созданная валовая добавленная стоимость в обрабатывающей промышленности ведущих стран. Постепенное снижение промышленного производства в Украине в течение 2010-2018 гг. привело к тому, что страна входит в новый технологический цикл, не имея мощной промышленной базы. Это определяет ее низкие стартовые возможности для внедрения конструкторских инноваций и дальнейшего устойчивого развития. Предложено сформировать промышленную робототехнику как ведущую нишу в промышленности страны, которая стала бы точкой роста для экспорта продукции с высокой добавленной стоимостью. Такой выбор обусловлен социально-экономическим прогрессом человечества в 21 веке и показателями развития промышленной робототехники за последние годы.

Ключевые слова: промышленная политика, технологический уклад, ниша, робототехника, промышленный мультипликатор, волна Кондратьева, обрабатывающая промышленность, валовая добавленная стоимость, модель, Украина. 
О. І. Карінцева, А. В. Дяченко, С. В. Тарасенко, М. О. Харченко. Передумови формування промислової політики країни в умовах переходу до шостого технологічного укладу

Mechanism of Economic Regulation, 2018, No 4, 45-53

ISSN 1726-8699 (print)

Передумови формування промислової політики країни

в умовах переходу до шостого технологічного укладу

\section{ОЛЕКСАНДРА ІвАНІвНА КАРІНЦЕВА*, АННА ВІКТОРІвНА ДяченКо ${ }^{* *}$, СвітЛАНА ВІКТорівНА ТАРАСЕНКО***, МИКОЛА ОЛЕКСІйОВИч ХАРЧЕНКО $* * * *$}

* кандидат економічних наук, дочент, дочент кафедри економіки, підприємництва та бізнес-адміністрування Сумського державного університету, вул. Р.-Корсакова, 2, м. Суми, 40007, Украӥна, тел.: 00-380-542-332223,e-mail: niko_kha@ukr.net

** аспірант кафедри економіки, підприємництвва та бізнес-адміністрування Сумського державного університету, вул. Р.-Корсакова, 2, м. Суми, 40007, Україна, тел.: 00-380-542-332223, e-mail: a15dyachenko@gmail.com

**** кандидат економічних наук, стариий викладач кафедри міжнародних економічних відносин Навчально-наукового інституту бізнес-технологій «УАБС» Сумського державного університету, вул. Р.-Корсакова, 2, м. Суми, 40007, Україна, тел.:00-380-542-665042,e-mail:svitlana_tarasenko@ukr.net

***** кандидат економічних наук, доцент, доцент кафедри економіки, підприємництва та бізнес-адміністрування Сумського державного університету, вул. Р.-Корсакова, 2, м. Суми, 40007, Украӥна, тел.: 00-380-542-332223, e-mail: niko_kha@ukr.net

Актуальність дослідження. В умовах переходу до шостого технологічного укладу актуальним $\epsilon$ визначення вектору формування промислової політики та точок росту країни 3 урахуванням особливостей іiі розвитку та потенційних ресурсів. Для України актуальним залишається вибір ніші, галузі, напрямків, які б сформували основу сталого розвитку країни. Мета дослідження. Обгрунтування гіпотези про необхідність формування нішевої спрямованості промислової політики країни в умовах переходу до шостого технологічного укладу. Результати дослідження. Для України характерна класична модель промислової політики. В умовах децентралізації та необхідності рівномірного розвитку регіонів для країни оптимальним є використання системної моделі, яка ініціює диверсифікацію виробництва товарів і послуг і оптимізацію витрат у галузях. Важливим елементом в рамках кластерної моделі виступає визначення основної ніші, що об'єднує інноваційні кластери територій. В Україні простежується позитивна динаміка зростання доданої вартості, створеної в країні, до 2010 р При цьому абсолютні значення показника валової доданої вартості, створеної в цілому в Україні, в кілька разів менше (а то і в 10 разів), ніж створена валова додана вартість в обробної промисловості провідних країн. Поступове зниження промислового виробництва в Україні впродовж 2010-2018 рр. призвело до того, що країна входить в новий технологічний цикл, не маючи потужної промислової бази. Це визначає іiі низькі стартові можливості для впровадження конструкторських інновацій та подальшого сталого розвитку. Запропоновано сформувати промислову робототехніку як ведучу нішу в промисловості країни, яка б стала точкою зростання для експорту продукції з високою доданою вартістю. Такий вибір обумовлений соціально-економічним поступом людства у 21 столітті і показниками розвитку промислової робототехніки за останні роки. 
Oleksandra I. Karintseva, Anna V. Dyachenko, Svitlana V. Tarasenko, Mykola O. Kharchenko. Prerequisites for the Industrial Policy Formation of the Country in Conditions of Transition to the Sixth Technology Revolution

Ключові слова: промислова політика, технологічний уклад, ніша, робототехніка, промисловий мультиплікатор, хвиля Кондратьєва, обробна промисловість, додаткова вартість, модель, Україна.

JEL Codes: E22, G31, Q50, R11

Tables: 3; References: 15

Language of the article: English

תimepamypa

1. Behrens, K. Agglomeration and clusters: Tools and insights from coagglomeration patterns / K. Behrens // Canadian Journal of Economics. - 2016. - T. 49. - №. 4. - P. 1293-1339.

2. Дейнеко, Л. В. Неоіндустріальна трансформація промислового потенціалу України : колективна монографія / [Дейнеко Л. В., Шовкун І. А., Шелудько Е. І. та ін.] / за ред. д-ра екон. наук, проф. Л. В. Дейнеко; НАН України, ДУ «Ін-т екон. та прогнозув. НАН України». К., 2016. $-278 \mathrm{c}$.

3. Гринин, Л. Е. Н. Д. Кондратьев:кризисы и прогнозы в свете теории длинных волн. Взгляд из современности / под ред. Л. Е. Гринина, А. В. Коротаева, В. М. Бондаренко. - М. : Моск. ред. изд-ва «Учитель», 2017. - 384 с.

4. Кіндзерський, Ю. В. Антикризова промислова політика: варіант вітчизняного концепту / Ю. В. Кіндзерський // Вісник НАН України. - 2016. - № 10. - С. 27-42.

5. Хаустова, В. E. Промислова політика в Україні в умовах інтеграції та глобалізації економіки : дис. на здобуття ступеня доктора економічних наук за спеціальністю 08.00 .03 - економіка та управління національним господарством / В. Е. Хаустова. - К., 2015. - 505 с.

6. Отчет о промышленном развитии 2018. Спрос на продукцию обрабатывающей промышленности: фактор всеохватывающего и устойчивого промышленного развития. UNIDO. Вена, 2017.

7. Рифкин, Дж. Третья промышленная революция. Как горизонтальные взаимодействия меняют энергетику, экономику и мир в целом / Дж. Рифкин. - М. : Альпина нон-фикшн, 2014. - 410 с.

8. Смородинская, Н. В. Глобализированная экономика: от иерархий к сетевому укладу / Н. В. Смородинская. - М. : ИЭ РАН, 2015. - 344 с.

9. Сбербанк представил обзор мирового рынка робототехники [Электронний ресурс]. - Режим доступа : http://www.nanonewsnet.ru/news/2018/sberbank-predstavil-obzor-mirovogo-rynkarobototekhniki.

10. Доклад о мирових инвестициях 2017. Инвестиции и цифровая экономика. - ЮНКТАД, 2017.

11. Value added by activity [Electronic resource] - Accessed mode : https://data.oecd.org/natincome/value-added-by-activity.htm.

12. Державна служба статистики України [Електронний ресурс]. - Режим доступу : http://www.ukrstat.gov.ua.

13. Manufacturing-facts 2016 [Electronic resource]. - Accessed mode : https://mapifoundation.org/manufacturing-facts/2016/9/13/how-important-is-us-manufacturingtoday.

14. Manufacturing's Multiplier Effect is Stronger than Other Sectors' [Electronic resource] - Accessed mode : http://www.themanufacturinginstitute.org/Research/Facts-About-Manufacturing/Economyand-Jobs/Multiplier/Multiplier.aspx.

15. Индекс промышленного производства [Электронний ресурс] - Режим доступа : https://index.minfin.com.ua/economy/index/industrial/. 